\title{
ENVIRONMENT AND DEVELOPMENT: FORMULATION AND IMPLEMENTATION OF THE RIGHT TO DEVELOPMENT AS A HUMAN RIGHT*
}

\author{
Antônio Augusto Cançado Trindade**
}

\section{INTRODUCTORY REMARKS: HUMAN RIGHTS AND THE ENVIRONMENT}

In a recent study we have drawn attention to affinities in the parallel evolutions of human rights protection and of environmental protection ${ }^{1}$ which seem deserving of closer attention. International regulation in both domains of protection has taken place in the form of responses to specific challenges or threats; one and the other have undergone a process of internationalization and, more recently, of globalization. ${ }^{2}$ The indivisibility of human rights, and the emergence of global environmental issues, as common concern of mankind, ${ }^{3}$

\footnotetext{
* The original text served as a basis for one of the author's lectures in the Inter-American Seminar on Human Rights and the Environment (Brasilia, 4-7 March 1992) and will serve as part of a book currently in the course of preparation by the author on Human Rights Protection and Environmental Protection: A Parallel.

** Professor of International Law, University of Brasilia and Brazil's Rio-Branco Diplomatic Academy; Judge ad hoc, Inter-American Court of Human Rights; Member of the Board of Directors, Inter-American Institute of Human Rights.

1 A.A. CANÇADo TRINDAde, "The Parallel Evolutions of International Human Rights Protection and of Environmental Protection and the Absence of Restrictions upon the Exercise of Recognized Human Rights", 13 Revista del Instituto Interamericano de Derechos Humanos (1991) pp. 35-76. 2 Cf. ibid, pp. 37-47.

3 Cf. A.A. Cançado Trindade and D. Attard, "The Implications of the 'Common Concern of Mankind' Concept on Global Environmental Issues", in Policies and Laws on Global Warming:, International and Comparative Analysis (ed. T. IwAMA, Tokyo, Environmental Research Centre, 1991, pp. 7-13; and cf. UNEP, The Meeting of the Group of Legal Experts to Examine the Concept of the Common Concern of Mankind in Relation to Global Environmental Issues (Malta, 1990), Valletta/Nairobi, 1991, report by A.A. CANÇADO TRINDADE and D.J. ATTARD, pp. 19-26.
}

Asian Yearbook of International Law, Volume 3 (Ko Swan Sik et al., eds.; 0-7923-2708-X; (C) 1994 Kluwer Academic Publishers; printed in Great Britain), pp. 15-45 
bear witness of this phenomenon. The globalization of the regimes of human rights protection and environmental protection ${ }^{4}$ heralds the decline and end of reciprocity in those domains and the emergence of erga omnes obligations.

Just as concern for human rights protection can be found in the realm of international environmental law (Preamble and Principle 1 of the 1972 Stockholm Declaration on the Human Environment; Preamble and Principles 6 and 23 of the 1982 World Charter for Nature; Principles 1 and 20 proposed by the World Commission on Environment and Development in its 1987 report), ${ }^{5}$ concern for environmental protection can also be found in the express recognition of the right to a healthy environment in two recent human rights instruments, namely: the 1988 Additional Protocol to the American Convention on Human Rights in the Area of Economic, Social and Cultural Rights (Article 11) and the 1981 African Charter on Human and Peoples' Rights (Article 24). In the former, it is recognized as a right of "everyone" (\$ 1), to be protected by the States Parties ( $\S 2)$, whereas in the latter it is acknowledged as a peoples' right. ${ }^{6}$

Concern for the protection of the environment likewise can now likewise be found in the realm of international humanitarian law, namely: Articles 35(3) and 55 of the 1977 Additional Protocol I to the 1949 Geneva Conventions (prohibition of methods or means of warfare severely damaging the environment), added to the 1977 UN Convention on the Prohibition of Military or Any Other Hostile Use of Environmental Modification Techniques, and to the 1982 World Charter for Nature (paras 5 and 20), among other provisions. ${ }^{7}$ Similarly, recent developments in international refugee law are worthy of attention, such as the possible assimilation of victims of environmental disasters to protected [displaced] persons under refugee law (e.g., the 1984 Cartagena Declaration on Refugees, recommending for use in Central America an expanded concept of refugee). ${ }^{8}$

4 On the relationship between human rights and the environment, cf. further A.A. CANÇADo TRINDADE, Human Rights and the Environment, Report commissioned by UNEP's Environmental Law and Institutions Programme Activity Center, Nairobi/Brasilia, 1991, pp. 1-22 (restricted circulation); and cf. UNEP, Beijing Symposium on Developing Countries and International Environmental Law (August 1991), Beijing/Nairobi, 1991, Report by A.A. CANÇADO TrINDADE and A. MalHotra, p. 7.

5 Cf. A.A. Cançado Trindade, "The Contribution of International Human Rights Law to Environmental Protection, with Special reference to Global Environmental Change", in International Law and Global Environmental Change: New Dimensions (ed. E. BroWN WEISs), United Nations University (UNU) Project, 1992, 93 pp. (in print).

$6 \mathrm{Cf}$. ibid (in print).

7 Cf. ibid.

8 Furthermore, the protection of vulnerable groups (e.g., indigenous populations, ethnic and religious and linguistic minorities, mentally and physically handicapped persons) appears today at the confluence of international human rights law and international environmental law: as we have indicated in another study, concern for the protection of vulnerable groups can nowadays be found in international instruments and initiatives pertaining to both human rights protection and 
In fact, the fundamental rights to life and to health lie at the basis of the ratio legis of international human rights law and of environmental law. Taken in its wide and proper dimension, the fundamental right to life comprises the right of every human being not to be deprived of his life (right to life, belonging to the realm of civil and political rights) ${ }^{9}$ and the right of every human being to have the appropriate means of subsistence and a decent standard of life (preservation of life, right of living, belonging to the domain of economic, social and cultural rights). ${ }^{10}$ It affords an eloquent illustration of the indivisibility and interrelatedness of all human rights. International supervisory organs such as the Human Rights Committee (on distinct occasions) and the European Commission of Human Rights (e.g., in the Association $X \mathrm{v}$ United Kingdom case, 1978) have espoused the view that the right to life imposes upon States also positive measures to protect life. ${ }^{11}$

\section{THE SIGNIFICANCE OF THE RECOGNITION OF THE RIGHT TO A HEALTHY ENVIRONMENT}

From this perspective, the right to a healthy environment appears as a natural extension of the right to life, in so far as it safeguards human life itself under the two aspects of the physical existence and health of human beings, and the dignified conditions and quality of life. The right to a healthy

cont.

environmental protection, where the issue has been approached on the basis of both human and environmental considerations (cf. references and sources in 10 cit. n.5.

9 Cf. UN Covenant on Civil and Political Rights, Article 6 (1); European Convention on Human Rights, Article 2; American Convention on Human Rights, Article 4(1); African Charter on Human and Peoples' Rights, Article 4.

10 Cf. UN Covenant on Economic, Social and Cultural Rights, Articles 11-12, following Article 25(1) of the 1948 Universal Declaration of Human Rights.

11 In its general comments 6 (16), of 1982, and 14 (23) of 1985, the Human Rights Committee has advanced a particularly wide interpretation of the right to life (as enshrined in Article 6 of the UN Covenant on Civil and Political Rights) to the point of expressing its concern with the current proliferation of weapons of mass destruction representing one of the "gravest threats" to the right to life which "confronts mankind" today. And both the UN General Assembly and the InterAmerican Commission of Human Rights have on distinct occasions been attentive to address the requirements of survival as components of the right to life. In this respect, the UN General Assembly (Resolution 37/189A, of 1982) as well as the UN Commission on Human Rights (Resolutions 1982/7, of 1982, and 1983/43, of 1983) have firmly propounded that all individuals and all peoples have an inherent and foremost right to life, the safeguard of which is an essential condition for the enjoyment of the entire range of civil and political, as well as economic, social and cultural rights. This brings to the fore the safeguard of the right to life of all persons as well as of all human collectivities, with special attention to the requirements of survival (as component of the right to life) of vulnerable groups. Cf. A.A. CANÇADO TRINDADE, “The Parallel Evolutions ...", loc. cit. n. 1 at pp. 50-59, and sources referred to therein. 
environment thus encompasses and enlarges the right to health and the right to an adequate standard of living. ${ }^{12}$ Thus, the basic right to life, encompassing the right of living, entails negative as well as positive obligations in favour of preservation of human life: its enjoyment is a precondition of the enjoyment of other human rights. It belongs at a time to the realm of civil and political rights and to that of economic, social and cultural rights, thus illustrating the indivisibility of all human rights. It establishes a "link" between the domains of international human rights law and environmental law. It inheres in all individuals and all peoples, with special attention to the requirements of survival. It has as extensions or corollaries the right to a healthy environment and the right to peace (and disarmament). It is closely related, in its wide dimension, to the right to development as a human right (right to live with fulfilment of basic human needs). And it lies at the basis of the ultimate ratio legis of the domains of international human rights law and environmental law, turned to the protection and survival of the human person and mankind.

Inextricably interwoven with the right to life itself, the right to health entails negative obligations (not to practice any act which can endanger one's health, thus linking this basic right to the right to physical and mental integrity and to the prohibition of torture and of cruel, inhuman or degrading treatment ${ }^{13}$ as well as positive obligations (to take all appropriate measures to protect and preserve human health, ${ }^{14}$ including measures of prevention and treatment of diseases). It thus partakes the nature of an individual and a social right: it is, like the right to life, an individual right in that it requires the protection of the physical and mental integrity of the individual, and it is also a social right in that it imposes on the State and on society the collective responsibility for the protection of public health. The right to health, thus properly understood, affords, like the right to life, a vivid illustration of the indivisibility and interrelatedness of all human rights. It can hardly be doubted that

12 It should not pass unnoticed that the 1989 Hague Declaration on the Atmosphere, for example, expressly refers to the right to live (\$1 and 5), seemingly well in keeping with the proper understanding that the right to life entails negative as well as positive obligations as to preservation of human life.

13 As recognized and provided for in the UN Covenant on Civil and Political Rights, Article 7; the European Convention on Human Rights, Article 3; the American Convention on Human Rights, Articles 4-5.

14 Cf. UN Covenant on Economic, Social and Cultural Rights, Article 12; European Social Charter, Article 11; besides WHO and ILO resolutions on specific aspects.

15 The collection Case Law on the European Social Charter, for example, contains illustrative views of the Committee of Independent Experts pertaining to the content and extent of the right to protection of health as enshrined in Article 11 of the 1961 European Social Charter. Reference could also be made to the 1973 Draft Protocol to the European Convention on Human Rights, prepared by H. STEIGER, which provided for the protection of life and health as encompassing wellbeing (Article $1(1)$ ) and the protection of individuals against acts of other private persons (Article 2), which remains the sole existing proposal on the matter to date (in so far as the European Convention system is concerned). Cf. A.A. CANÇADO TRINDADE, loc. cit. n. 1 at pp. 61-62. 
environmental degradation constitutes a collective threat to human health; ${ }^{15}$ in fact, the protection of the whole of the biosphere as such entails the protection of human beings, and the right to a healthy environment comes to enhance the protection of other recognized human rights. ${ }^{16}$

If the right to a healthy environment is taken not as the (virtually impossible) right to an ideal environment but rather as the right to the conservation-i.e. protection and improvement-of the environment, it can then be implemented like any other individual right. A healthy environment is then taken as a "procedural" right, the right to a due process before a competent organ, and thus assimilated to any other right guaranteed to individuals and groups of individuals. This right entails, as corollaries, the right of the individual concerned to be informed of projects and decisions which could threaten the environment ${ }^{17}$ (the protection of which counts on preventive measures), and the right of the individual concerned to participate in the taking of decisions which may affect the environment (active sharing of responsibilities in the management of the interests of the whole collectivity). ${ }^{18}$ To the rights to information and of participation one can add the right to available and effective domestic remedies. The 1982 World Charter for Nature, it may be recalled in this respect, does in fact provide ( $\$ 23)$ that all persons are to have the opportunity to participate -individually or with others-in the formulation of decisions of direct concern to their environment and, furthermore, are to have access to means of redress when their environment has suffered damage or degradation.

16 At the global level, the E.H.P. v Canada case (1982), decided by the Human Rights Committee under the UN Covenant on Civil and Political rights and [first] Optional Protocol bore witness of the interrelatedness between environmental protection and human rights protection, in particular when fundamental rights, such as the rights to life and to health, are at stake. Cf. Selected Decisions of the Human Rights Committee under the Optional Protocol, Vol. 2 (UN 1990, Doc. CCPR/C/OP/ 2) pp. 20-22.

17 On the possibility of interpreting the European Convention on Human Rights as containing (as from the provisions of, e.g., Articles 10, 8 and 2) the right to environmental information, and for the suggestion that this right be embodied in a possible new Additional Protocol to the European Convention, cf. S. WEBER, "Environmental Information and the European Convention on Human Rights”, 12 Human Rights Law Journal (1991) pp. 177-185.

18 A. Ch. Kiss, "Le droit à la qualité de l'environnement: un droit de l'homme?", Le droit à la qualité de l'environnement: un droit en devenir, un droit à définir (ed. N. DuPLÉ), Vieux-Montréal/ Québec, Éd. Québec/Amérique, 1988, pp. 69-87; and cf. A. Ch. Kiss, "Peut-on parler d'un droit à l'environnement?", Le droit et l'environnement-Actes des Journées de l'Environnement du C.N.R.S. (1988) pp. 309-317. 


\section{3. "SUSTAINABLE DEVELOPMENT" AS A LINK BETWEEN THE RIGHT TO A HEALTHY ENVIRONMENT AND THE RIGHT TO DEVELOPMENT}

The right to a healthy environment can hardly be approached in isolation; it has found expression in the conceptual universe of human rights. It cannot be considered without reference to another right of the kind, namely, the right to development as a human right. It may well be that the principle of sustainable development-which, in the view of the Brundtland Commission, calls for meeting the needs and aspirations of the present without compromising the ability of future generations to meet their own needs-provides a possible link between the right to development and the right to a healthy environment. It emphasizes that environment and development go together, applying to developed as well as developing regions of the world and creating obligations for all, while bearing in mind the international community as a whole and the present as well as future generations: in this sense sustainable development has come to be regarded not only as a concept, but as a principle of contemporary international law. ${ }^{19}$ The UN General Assembly, in deciding to convene the 1992 UN Conference on Environment and Development asserted and insisted on the promotion of sustainable and environmentally sound development in all countries. ${ }^{20}$ In fact, assertions of the interrelationship between environment and development have come from all corners.

At regional level, for example, the 1988 Berlin Round-Table on Environment, Natural Resources and North-South Interdependence stated that sustainable development was "needed both in the North and in the South', and it required that those who were more affluent adopt "lifestyles compatible with the planet's finite ecological means"; it drew attention to the "environmental dimension in development projects" and added that "development activities must be socially, culturally and environmentally compatible".21

The Beijing Ministerial Declaration on Environment and Development, of June 1991, expressing the views of 41 participating developing countries, began by attributing the acceleration of environmental degradation to "unsustainable development models and lifestyles" ( $(1)$ and by stressing the need to integrate environmental protection with the imperatives of sustainable development as a matter of common concern of mankind ( $\$ 2-3$ ); it then warned that the

19 NAGEndRa Singh, "Sustainable Development as a Principle of International Law", in International Law and Development (ed. P. De WAART, P. Peters and E. DenTERs), Dordrecht, Nijhoff, 1988, pp. 2-5.

20 Cf. G.A. Resolution 44//228, of 22 December 1989, paras 3, 6, 12 and 15(c) and (i).

21 Council of Europe, Results of Round-Tables and Other European Events in the Context of the North-South Campaign (Doc. CEO/NS/TR (88) 10, Strasbourg, C.E. Secretariat, 1988) pp. 34-35 and 38. 
environmental problems of the developing countries arose from the conditions of poverty, and that sustainable development and steady economic growth constituted "a way to break this cycle of poverty and environmental degradation and to strengthen the capabilities of the developing countries for environmental protection" ( $(4)$. In emphasizing the interrelationship between environment and development issues (\$\$ 25-26), the Beijing Declaration further stated that as poverty was "at the root of the environmental problems of the developing world" ( $\$ 27)$, it was necessary to keep pursuing endeavours to attain "better quality of life and environmental well-being" and "to protect the environment without hindering the development process" ( $\$ 30$ and 32).

The Beijing Symposium on Developing Countries and International Environmental Law, of August 1991, co-sponsored by UNEP, the Chinese Ministry of Foreign Affairs in cooperation with the United Nations and the Chinese Society of International Law in the framework of the UN Decade of International Law, acknowledged in its final report ${ }^{22}$ that environment and development were indivisible and could not be considered in isolation from each other, the concept of common concern of mankind relating both to environment and to development (p.4). The Beijing Symposium report reckoned that the environmental problems of developing countries were "often a reflection of the inadequacy of development", and drew attention to the "vicious circle linking poverty, underdevelopment and environmental degradation"; it added that sustainable development included the fostering of economic growth, the meeting of basic domestic human needs (e.g., those pertaining to health, nutrition, education, housing) and "the eradication of poverty so as to provide to all a life of dignity in a clean, safe and healthy environment". In this respect, the report asserted that "there were linkages" between the domains of environmental protection and of human rights protection "provided mainly by the focus on certain fundamental rights (inter alia, the right to life and the right to health)" and that "the emergence of the right to a healthy environment and the right to development was meant to enhance, rather than to restrict, other rights, given their indivisibility and interrelatedness" (p.5).

Reference could also be made to the Ministerial Declaration on Environmentally Sound and Sustainable Development, adopted by the Bangkok Meeting of October 1990, reflecting the views of countries in Asia and the Pacific region. As a follow-up of that Ministerial Meeting, a Meeting of Senior Officials, convened in Bangkok in February 1991, adopted a report to the Economic and Social Commission for Asia and the Pacific (ESCAP) in which it pointed out the "environment-development interaction" ( $\$ 21$ (d)), and addressed, inter alia, the issues of human health and quality of life ( $\$ 52)$; as "poverty and underdevelopment are the major causative factors of environmental problems

22 Rapporteurs A.A. CANÇADo tRINDADE (Brazil) and A. MAlhotra (India). 
for the developing countries in the region", the major objective of the strategy of these latter was "to ensure sustainable development for meeting basic human needs for survival and for improvement in the quality of life" (\$21 (a)).

In its turn, the Brasilia Declaration on the Environment, adopted at the Latin American and Caribbean Summit (VIth Ministerial Meeting) of March 1989, affirmed that the improvement of economic and social conditions of life was "the key to preventing the defacement of the environment" in the countries of the region (\$3). Likewise, the Action Plan for the Environment in Latin America and the Caribbean, adopted by the VIIth Ministerial Meeting on the Environment in Latin America and the Caribbean (held in Port-of-Spain, Trinidad and Tobago) in October 1990, recalled the Brasilia Declaration and insisted on the "inseparable linkage" between environmental concerns and the development model (\$\$ 3-4 of "Call to Action"). ${ }^{23}$ The Tlatelolco Platform on Environment and Development, adopted at the Latin American and Caribbean Regional Ministerial Preparatory Meeting of March 1991 for the 1992 UN Conference on Environment and Development, went further than the 1989 Brasilia Declaration in identifying priority concerns of the countries of the region and calling for their joint action for the 1992 Conference (\$ 24-25). The 1991 Tlatelolco Platform acknowledged the link between poverty and environmental degradation ( $\$ 18$ and $24(\mathrm{~g})$ ) and the link between such degradation and unsustainable development models ( $\$ 2,4,6$ and 9): it called for the incorporation of the "environmental dimension" as a basic component of the process of sustainable and equitable development ( $\$ 23$ and 13) and then drew attention to the related relevance of observance of human rights. In that respect, the Tlatelolco Platform emphasized the region's "significant achievements in strengthening democratic processes, preserving peace and promoting respect for human rights" ( $(3)$, as well as the need to secure "access to decent living conditions, adequate levels of social organization and political representation and the genuine participation of the population in the definition of its own development" $(\S 18)$. The Tlatelolco Platform insisted on "the essential need for the active commitment of all sustainable development" (\$21). There was thus clear recognition of the interrelationship between environmental protection, sustainable development and human rights promotion and protection.

Last but not least, the report Our Own Agenda (1990), prepared by the Latin American and Caribbean Commission on Development and Environment to develop a regional outlook on the issue of the environment prior to the 1992

23 The participating countries in the VIIth Ministerial Meeting further stated, inter alia, that there was "an unbreakable bond between environmental deterioration and poverty", and that "environmental protection must become an integral part of the economic, social and cultural development of the nations of the region". Doc. UNEP/LAC-IG-VII/4, of 23 October 1990, Annex II, pp. 3-4. 
UN Conference on Environment and Development, likewise drew attention to the relevance to that central issue of securing respect for human rights. The report stated categorically that

"to speak of human rights (including the right to eat, to housing, to education, to health, and to income), of the environment, or of support for democracy and cultural diversity is infinitely more logical from the human perspective" (p.11).

The report next warned in this connection that "our region has experienced a democratization process that should be sustained. The broad participation of civilian society is essential if we are to achieve development with equity" (p.IX). Sustainable development will thus not be possible without real democracy: it will be "impossible to break down the barriers that stand in the way of economic, social and ecologically viable development" without a "democracy that permits greater participation by society" (p.45). Achievement of sustainable development should be "the joint responsibility of State and society", that presupposes the existence of a well-informed society, a social mobilization on behalf of sustainable development, and "the citizens' ability to control the State"; a participating democracy is characterized by "a proliferation of organizations which serve as intermediaries between the State and society" (pp. 72-75).

The regional Latin American and Caribbean report goes on to identify distinct ways to strengthen the constitutional State, namely: first, the development of adequate environmental legislation ${ }^{24}$ (with corrective as well as, mainly, preventive measures, also requiring environmental impact studies); second, the introduction of reforms that make "the judicial power truly autonomous"; and third, the establishment of the basis for "a legal system that protects the citizens against abusive exercises of power" (pp.78-79). Significantly, the report Our Own Agenda emphasizes that the central objective of the new strategy to stimulate sustainable development pursuant to such regional outlook

\footnotetext{
"can be none other than the improvement of the quality of life of the population. If we are to improve the quality of life, we must, first and foremost, face up to the abject poverty which currently affects the bulk of the population. We cannot talk of improving the environment as long as such a sizeable segment of our people lives in conditions of extreme poverty" (p.45).
}

Therefore, the fundamental aim of the economic and social strategy is "to

24 For a recent study of environmental legislation in Latin American and Caribbean countries, see Institutional and Legal Aspects of the Environment in Latin America, Including the Participation of Non-governmental Organizations in Environmental Management, Washington (Inter-American Development Bank, 1991) pp. 11-47 and 104-105. 
enhance the well-being of most of the population to the fullest", in conformity with the "objectives of sustainable development", leading necessarily to a "more egalitarian society" (p.68). The regional report thus clearly stresses the link between pursuance of ecologically sustainable development and enhancement of human rights, in particular economic and social rights.

Moving from the regional to the global level, it may be recalled that the concept (or principle) of "sustainable development" occupied a central place in the already-mentioned 1987 report of the World Commission on Environment and Development. The relevant passages of the Brundtland Commission report, besides linking environmental and developmental considerations, addressed the issues of elimination of poverty and satisfaction of essential human needs. ${ }^{25}$ The Report is permeated with considerations of [inter-and intra-generational] equity, ${ }^{26}$ social justice, ${ }^{27}$ regulated access to resources and human resource development, ${ }^{28}$ effective community and citizen participation, ${ }^{29}$ wide and effective international cooperation "to manage ecological and economic interdependence". ${ }^{30}$ It sets policy directions to attain sustainable development in six areas, namely: population and human resources; food security; the loss of species and genetic resources; energy; industry; and human settlements (the urban challenge). ${ }^{31}$ The Commission also refers to international humanitarian law, ${ }^{32}$ and attempts to formulate the fundamental human right to an adequate and healthy environment. ${ }^{33}$

The Brundtland Commission report is particularly emphatic in insisting that the very concept of sustainable development requires the eradication of widespread or extreme poverty and the adoption by the more affluent of lifestyles considerably less consumist and more consonant with the world's [limited] ecological means: ${ }^{34}$ in the endeavours towards sustainable development, "overriding priority" should be given to the "essential needs of the world's poor", 35 as "poverty, injustice, environmental degradation, and conflict interact in complex and potent ways". ${ }^{36}$ After all, development and environmental protection go together, in an indivisible and integrated way; they cannot be considered in isolation from each other, and they are both

25 Cf. World Commission on Environment and Development, Our Common Future (Oxford, Oxford University Press, 1987) pp. 8-9, 40, 43-66, 75-90.

26 Ibid, p. 52.

27 Ibid, pp. 40 and 49.

28 Ibid, p. 11.

29 Ibid, pp. 63 and 65.

30 Ibid, p. 9, and cf. pp. 65 and 301.

31 Cf. ibid, pp. 11 and 95-258.

32 Cf. ibid, pp. 290 and 294-300.

33 Cf. $\S 1$, in ibid, Annex 1, p. 348.

$34 \mathrm{Ibid}$, pp. 8-9, and cf. pp. 29-31, 40 and 49.

$35 \mathrm{Ibid}$, p. 43 (emphasis added), and cf. p. 54.

36 Ibid, p. 291 
regarded today as being together of common concern for mankind.

The 1991 Human Development Report of the United Nations Development Programme (UNDP), referring to sustainable development, likewise warns as to the interrelationship between poverty and environmental degradation. ${ }^{37}$ In its turn, the 1987 UNEP report on "Environmental Perspective to the Year 2000 and Beyond", in addressing sustainable development also asserts that "environmental issues are closely intertwined with development policies and practices", 38 and further warns:

"[S]ince mass poverty is often at the root of environmental degradation, its elimination and ensuring equitable access of people to environmental resources are essential for sustained environmental improvements". ${ }^{39}$

The UNEP report acknowledges the need for "more concern for human progress and social justice as factors influencing human resources development and environmental improvement", ${ }^{40}$ and calls for the provision by governments of basic health and housing development as an integral part of environmental management of resources so as to ensure better quality of life for their people. ${ }^{41}$ In the view of the UNEP report, "poverty-focused projects which improve the environment should receive greater attention in development cooperation". 42

Sustainable development discloses a pronounced temporal dimension; in fact, an essential element of sustainability is the basic general obligation to look into the future. ${ }^{43}$ In the acknowledgement and assertion of the requirements of survival and of superior common principles and values and common responsibility, one can witness the notion evolving in contemporary international law that "obligations and entitlements are no longer the sole attributes of States but first and foremost pertain to human beings and to peoples". ${ }^{44}$ Bearing this in mind, we can turn our attention to the significant formulation, at global (United Nations) level, of the right to development as a human right, as the latter is directly related to the right to a healthy environment.

The 1986 UN Declaration on the Right to Development ${ }^{45}$ states quite clearly

37 PNUD, Desarrollo Humano: Informe 1991, Bogotá, PNUD/Tercer Mundo ed., 1991, pp. 184 185.

38 UNEP/Governing Council, Environmental Perspective to the Year 2000 and Beyond, Doc. UNEP/GC. 14-26, 1987, Annex II, p.4.

39 Ibid, p. 3, and cf. p. 6.

40 Ibid, p. 5.

41 Ibid, p. 24, and cf. pp. 21-22, 34 and 37.

42 Ibid, p. 27.

43 NAGENDRA SiNGH, op. cit. supra n. 19, p. 6.

44 Th. van Boven, "Fundamental Rights and Nuclear Arms", 19 Denver Journal of International Law and Policy (1990) pp. 58-59; and cf. R. MÓlLERson, "Right to Survival as Right to Life of Humanity", 19 Denver Journal of International Law and Policy (1990) pp. 48-50. 
that "the human person is the central subject of development and should be the active participant and beneficiary of the right to development" (Article 2 (1), and Preamble). It qualifies the right to development as "an inalienable human right" of "every human person and all peoples" (Article 1), by virtue of which they are "entitled to participate in, and contribute to, and enjoy economic, social, cultural and political development, in which all human rights and fundamental freedoms can be fully realized" (Article $1(1)$ ).

The Declaration addresses itself repeatedly to States, urging them to take all necessary measures for the realization of the right to development (Articles 3 (3), 4, 5, 6, 7 and 8). Responsibility for the realization of the right to development is placed primarily on States (Article 3 (1)), "individually and collectively" (Article 4 (1)), but also on all human beings, "individually and collectively" (Article 2 (2)), i.e., individuals and communities. The Declaration envisages measures and activities at both national and international levels (Articles $3(1), 4,8$ and 10) for the realization of the right to development. The Declaration thus encompasses a wide and complex range of relationships meant to contribute to the realization of the right to development.

\section{SUBJECTS, LEGAL BASIS AND CONTENTS OF THE RIGHT TO DEVELOPMENT AS A HUMAN RIGHT}

The 1986 Declaration clarified to some extent the key questions of the subjects, legal basis and contents of the right to development, much discussed in the preparatory work of the Declaration and in expert writing in the years

45 Adopted by General Assembly Resolution 41/128, of 4 December 1986, with 146 votes in favour, one against, and eight abstentions, and containing a Preamble with 17 paragraphs and 10 Articles in its operative part. For an account of the drafting of the Declaration, see inter alia, M. BuLAJC, Principles of International Development Law, Dordrecht, M. Nijhoff, 1986, pp. 332-345; J. Alvarez Vita, Derecho al Desarrollo, Lima, Cult. Cuzco Ed., 1988, pp. 8-108; M.M. KENIGWITKOwSKA, "The UN Declaration on the Right to Development in the Light of its Travaux Préparatoires", in International Law and Development (eds. P. De WAART, P. Peters and E. DENTERS), Dordrecht, M. Nijhoff, 1988, pp. 381-388. For recent reassessments of the Declaration, see generally: Ph. Alston, "Making Space for New Human Rights: The Case of the Right to Development", 1 Harvard Human Rights Yearbook (1988) pp. 3-40; G. ABI-SAAB. "Le droit au développement", 44 Annuaire suisse de droit international (1988) pp. 9-24; B.G. RAMCHARAN, "The Role of the Development Concept in the UN Declaration on the Right to Development and in the UN Covenant", in International Law and Development (eds. P. De WAART, P. PETERS and E. DeNTERs), Dordrecht, M. Nijhoff, 1988, pp. 295-303; J. CRAWfORD, "The Rights of Peoples: Some Conclusions", in The Rights of Peoples (ed. J. CrAwfORD), Oxford, Clarendon Press, 1988, pp. 172-174; IAN Brownlie, The Human Right to Development, London, Commonwealth Secretariat (Occasional Papers), 1989, pp. 1-25; A.A. CanÇAdo Trindade, "Legal Dimensions of the Right to Development as a Human Right: Some Conceptual Aspects", 12 Revista del Instituto Interamericano de Derechos Humanos (1990) pp. 81-95. 
which preceded it. ${ }^{46}$ As to the subjects, it is noteworthy that the Declaration proclaims the right to development as an inalienable human right, by virtue of which every human person and all peoples are entitled to enjoy economic, social, cultural and political development. The active subjects or beneficiaries of the right to development are thus the human beings and peoples. In addition, as what happens in contemporary formulation of other rights pertaining to human collectivities (or to the human person in society, or "l'homme ou peuple situé "), distinct sets of obligations ${ }^{47}$ may be distinguished: the responsibilities ascribed by the Declaration to States, individually and collectively, and, as counterpart of the human right to development, the responsibilities incumbent upon human beings, individually and collectively (communities, associations, groups). The passive subjects of the right to development are thus those who bear such responsibilities, with emphasis on the obligations attributed by the Charter to States, individually and collectively (the collectivity of States).

Possibly the major significance of the Declaration on the Right to Development lies in its recognition or assertion of the right to development as an "inalienable human right". The acknowledgement of this right of the human person and of peoples was intuitively forecasted or anticipated by a few authors some years ago. ${ }^{48}$ But even nowadays, in the first years following the Declaration, some precision is required as to the legal basis and contents of the right to development. The Declaration contains elements which are already embodied, mutatis mutandis, both in human rights instruments proper (such as the 1948 Universal Declaration, the two UN Covenants on Human Rights, and UN resolutions of various kinds on the subject) and in sources of the international law of development (such as the 1974 Charter of Economic Rights and Duties of States, the 1974 Declaration-and Programme of Action-on the Establishment of a New International Economic Order, and relevant UN General Assembly resolution). ${ }^{49}$

It is important to keep in mind the distinction between the "international law

46 Cf. the papers by R. AGo, R. ZACKLIN, G. ABI-SAAB and A. EIDE, in Le droit international au développement au plan international-Colloque (1979), Hague Academy of International Law (hereinafter quoted Hague Colloquy), The Hague, Sijthoff/Nijhoff, 1980, pp. 7-8 (AGO), 117-118 (ZACKLIN), 162-164 and 168-170 (ABI-SAAB), and 402-403 and 415 (EIDE).

47 I.J. KOPPEN and K.-H. LAUDEUR, Environmental Rights, Florence, European University Institute, 1989, p. 33 (2nd draft, internal circulation).

48 KÉBA M'BAYE, "Le droit au développement comme un droit de l'homme", 5 Revue des droits de l'homme/Human Rights Journal (1972) pp. 505-534; J.A. CARRILLO SALCEDo, "El Derecho al Desarrollo como Derecho de la Persona Humana", 25 Revista Española de Derecho Internacional (1972) pp. 119-125.

49 Cf., e.g., JoRge Castañeda, "La Charte des droits et des devoirs économiques des États", 20 Annuaire francais de droit international (1974) pp. 31-77; P.M. MARTIN, "Le nouvel ordre économique international", 80 Revue générale de droit international public (1976) pp. 502-535; P. de WAART, "Permanent sovereignty over natural resources as a cornerstone for international 
of development" ("droit international du développement "), and the "right to development" ("droit au développement") as a human right as proclaimed in the 1986 Declaration. The former, with its various components (right to economic self-determination, permanent sovereignty over natural wealth and resources, principles of non-reciprocal and preferential treatment for developing countries and of participatory equality of developing countries in international economic relations and in the benefits from science and technology), emerges as an objective international normative system regulating the relations among juridically equal but economically unequal States. It aims at the transformation of those relations on the basis of international cooperation (UN Charter, Articles 55-56) and considerations of equity, so as to redress the economic imbalances among States and to give all Statesparticularly the developing countries-equal opportunities to attain development. ${ }^{50}$ The latter, as propounded by the 1986 Declaration (and inspired in such human rights provisions as Article 28 of the 1948 Universal Declaration and Article 1 of both UN Covenants on Human Rights) appears as a subjective human right, embodying demands of the human person and of peoples which ought to be respected.

Three years after the adoption of the UN Declaration on the Right to Development, its significance has been acknowledged by some countries in their comments and views on the implementation and further enhancement of the Declaration forwarded to the UN Secretary-General and considered by the UN Commission on Human Rights in its 1989 session. According to these comments and views, the primary significance of the Declaration is reflected in the status of an "inalienable human right" given to the right to development (Jamaica), in the emphasis on the "all-embracing global" nature of the problem of development and its linkage to the observance of human rights (USSR), the awareness of the need of a "comprehensive realization" of all human rights (Yugoslavia), and in the recognition of the interdependence of all

cont.

economic rights and duties", 24 Netherlands International Law Review (1977) pp. 304-322; A.A. CANÇADO TRINDADE, "As Nações Unidas e a Nova Ordem Econômica Internacional", 81 Revista de Informação Legislativa, Brasilia (1984) pp. 213-232; H. HoHMANN, "Justice sociale et développement pour le nouvel ordre économique international", 58-59 Revue de droit international de sciences diplomatiques et politiques (1980-1981) pp. 217-231 and 82-88.

50 M. Virally, "Vers un droit international du développement", 11 Annuaire francais de droit international (1965) pp. 3-12; H. Gros Espiell, Derecho Internacional del Desarrollo, Valladolid, Univ. de Valladolid, 1975, pp. 11-47; P. BUIRETTE-MAURAU, La participation du tiers-monde d̀ l'élaboration du droit international, Paris, LGDJ, 1983, pp. 131-137, 160-167 and 185-202; ALAIN Pellet, Le droit international du développement, 2nd ed., Paris, PUF, 1987, pp. 3-124. 
human rights (Brazil and India). ${ }^{51}$ Furthermore, the right to development focuses on the interaction between human rights and development, ${ }^{52}$ at last brought together.

\section{IMPLEMENTATION (MISE-EN-OEUVRE) OF THE RIGHT TO DEVELOPMENT AS A HUMAN RIGHT}

The formulation and assertion of the right to development leads to the next question, that of its implementation or vindication. It should preliminarily be observed that the UN Declaration on the Right to Development itself was attentive to the obstacles to be overcome in order to provide equality of opportunity for development. The Declaration refers to the elimination of those obstacles in Articles 5 and 6(3), and two consideranda of the Preamble, and identifies them as being: massive and flagrant violations of rights of human beings and peoples (ensuing from situations such as those resulting from apartheid, all forms of racism and racial discrimination; foreign domination and occupation, aggression, foreign interference and threats against national unity and sovereignty and territorial integrity), threats of war and refusal to recognize the fundamental right of peoples to self-determination.

In addition, the [UN] open-ended Working Group of Governmental Experts on the Right to Development, originally established in 1981 by the UN Commission on Human Rights, recently considered (1989) as further obstacles to be surmounted for the realization of the right to development: the arms race and the threat of nuclear holocaust, poverty and destitution, illiteracy, economic imbalances in international relations, the deterioration of the environment and the ecological balance, ideological and religious intolerance, different forms of violence, and natural disasters. On the other hand, the Working Group also considered as factors which may foster the harmonious development of mankind, the progress in science and technology and the dissemination of knowledge and cultural values through information and

51 Analytical Compilation of Comments and Views on the Implementation and Further Enhancement of the Declaration on the Right to Development Prepared by the Secretary-General (UN Doc. E/ CN.4/AC.39/1989/1, of 21 December 1988) pp. 4-9.

52 Ph. Alston, "The right to development at the international level", Hague Colloquy, supra n. 46, p. 111. Cf. also J.-B. MARIE and N. QuestiAuX, "Article 55 alinéa c", in La Charte des Nations Unies-Commentaire article par particle (ed. J.-P. Cot and A. Pellet), Paris-Bruxelles, Economica/Bruylant, 1985, pp. 863-883; TH. vAN BoveN, "Human Rights and DevelopmentRhetorics and Realities", in Progress in the Spirit of Human Rights-Festschrift für Felix Ermacora (ed. M. NowaK, D. STEURER and H. TRETTER), Kehl/Strasbourg, N.P. Engel Verlag, 1988, pp. 575-587. 
communications media (so as to facilitate exchanges among men and cultures). ${ }^{53}$

Although the 1966 UN Covenant on Economic, Social and Cultural Rights falls short of expressly recognizing (especially in its Articles 11-12) the right to development, it appears that its draftsmen did have in mind development issues the implementation of which was related to the development process of each country. ${ }^{54}$ Thus, the insufficient level of socio-economic development is one of the sources of difficulties in the realization of the rights recognized in the Covenant $^{55}$ and the significance of the right to development may thus be assessed in terms of its impact on the fostering and operationalization of economic, social and cultural rights. ${ }^{56}$

All development models ought to conform to international human rights standards; the disparities of socio-economic development among countries and peoples-further exacerbated, in the case of developing countries, by the external debt problem - constitutes a threat to mankind. ${ }^{57}$ All aspects of the right to development (set forth in the 1986 UN Declaration) are indivisible and interdependent, encompassing economic, social, cultural, as well as civil and political rights; conditions of life include such basic needs as food, health, housing, education, a healthy environment as well as personal freedom and security.$^{58}$ Poverty and underdevelopment amount to a denial of the totality of human rights-civil, political, economic, social and cultural. Without housing or resources, one can hardly consider the right to health or the freedom of movement, without the means to raise one's own children the right to family life becomes dead letter, without education, one can hardly speak of freedom of expression or opinion and of association. ${ }^{59}$

An aspect which was particularly emphasized in the UN Global Consultation on the Right to Development as a Human Right (Geneva, 1990) was the importance of participation of all individuals and of the much-

53 Problems Related to the Right to Enjoy an Adequate Standard of Living-The Right to Development (UN Doc. E/CN.4/1989/10, of 13 February 1989) pp. 3-13. On the "individual" and "collective" dimensions of the right to development and the related theme of the external debt (of Latin American countries), cf. L. DiAz MülLER, "El Derecho al Desarrollo y los Derechos Humanos", 4 Revista del Instituto Interamericano de Derechos Humanos (1986) pp. 5-13.

54 B.G. RAMCHARAN, loc. cit. n. 45 at 298-299 and 301.

55 Ibid, pp. 299 and 301.

56 Рн. Alston, "Some Notes on the Concept of the Right to Development", in: Essais sur le concept de "droit de vivre" en mémoire de Y. Khushalani (ed. D. PRÉONT), Bruxelles, Bruylant, 1988, p. 84. On the "collective and communal characteristics" of African culture with an impact on its conception of the enjoyment of human rights, cf. T. HUARAKA, "The African Charter on Human and Peoples' Rights: A Significant Contribution to the Development of International Human Rights Law", in ibid, pp. 197, 201 and 204.

57 UN Centre for Human Rights, op. cit. n. 60 at pp. 27 and 46.

58 Cf. ibid, pp. 9-10, 44-45 and 49, and cf. pp. 15 and 42.

59 Ibid, p. 34. 
needed equality in the distribution or sharing of the benefits of development. ${ }^{60}$ Participation was viewed "as a means to an end and as an end in itself"; special measures were required "to protect the rights and ensure the full participation of particularly vulnerable sectors of society, such as children, rural people, and the extremely poor, as well as those which have traditionally experienced exclusion or discrimination, such as women, minorities and indigenous peoples". ${ }^{61}$ References were made in this connection to the need of an "appropriate environmental and cultural framework" in each country. ${ }^{62}$

The 1990 Global Consultation on the Right to Development, far from limiting itself to the States' domestic scene, also drew attention to the need, in the present domain, for "greater transparency in negotiations and agreements between States and international financial and aid institutions" and for democratization of intergovernmental financial agencies. Among the relevant factors for the assessment of the participatory process were mentioned "the representativity and accountability of decision-making bodies, the decentralization of decision-making, public access to information, and responsiveness of decision-makers to public opinion". ${ }^{63}$ It is significant that a Global Consultation convened by the UN Commission on Human Rights saw it fit to warn that "prevailing models of development have been dominated by financial rather than human considerations". These models

"largely ignore the social, cultural and political aspects of human rights and human development, limiting the human dimension to questions of productivity. They foster greater inequalities of power and control of resources among groups and lead to social tensions and conflicts. (...) The growing burden of indebtedness and structural adjustment falls heaviest on the poorest and weakest sectors of society and has clear human rights implications. (...) The prevailing terms of trade, monetary policy, and certain conditions tied to bilateral and multilateral aid, which are all perpetuated by the non-democratic decisionmaking processes of international economic, financial and trade institutions, also frustrate the full realization of the right to development as a human right".64

The same point was made in two recent regional Seminars of the InterAmerican Institute of Human Rights, held in Buenos Aires (1989) and in Brasilia (1991). The warning was expressed on those occasions that UN financial agencies (such as the IMF) seemed not to take into account provisions of UN human rights treaties and ILO conventions, and that this created a paradox within the UN system: it was important that international

60 UN Centre for Human Rights, The Realization of the Right to Development, New York, UN 1991 , pp. $25,35-38$ and 44.

61 Ibid, pp. 45-46, and cf. 33, 47 and 53.

62 Ibid, p. 53, and cf. pp. 47 and 45.

63 Ibid, pp. 50-51 (emphasis added).

64 Ibid, p. 48. 
financial agencies did not adopt measures-for instance, leading to persistent increases in the levels of unemployment and cost of living-which ran counter to the object and purpose of human rights treaties (adopted under the auspices of the UN itself and its specialized agencies). ${ }^{65}$ The effects of recessionist policies and the grave concentration of income, leading to the impoverishment of the population, constituted a threat, if not a violation, of economic and social rights, and ultimately of the right to development as a human right. ${ }^{66}$

In fact, even before the 1986 UN Declaration, the right to development as a human right was already recognized by a regional human rights convention: the African Charter on Human and Peoples' Rights states in its Article 22:

"All peoples shall have the right to their economic, social and cultural development with due regard to their freedom and identity and in the equal enjoyment of the common heritage of mankind".

It adds that "States shall have the duty, individually or collectively, to ensure the exercise of the right to development". Such express recognition of the right to development as a human right in both the African Charter and the 1986 UN Declaration is most significant, as the question of its implementation can be addressed once the right to development is properly inserted in the framework of human rights. ${ }^{67}$ Difficulties in that regard arise not only from its wide scope, covering a variety of entities and situations and placing unequal burdens (heavier on industrialized States), but also from the fact that it finds its roots partly in the tradition of human rights thinking (including the doctrine of collective rights) and partly in developments concerned with the establishment of a new international economic order. ${ }^{68}$

The implementation of the right to development and its practical implications within the framework of human rights has significantly

65 Cf. Derechos Económicos y Desarrollo en America Latina (eds. J. ORDóÑEZ and E. VASQUEZ), San José/Buenos Aires, IIDH, 1991, pp. 71 and 81-82.

66 A.A. CANÇADO TRINDADE, "The 1991 Brasilia Seminar on the Protection of Human Rights", 12 Human Rights Law Journal [1991] p. 346; A.A. CANÇADO TRINDADE (ed.), A Protegão dos Direitos Humanos nos Planos Nacional e Internacional: Perspectivas Brasileiras, San José/Brasilia, IIDH, 1992, p. 341. According to the sombre figures of the UNDP Human Development Report for 1991, the global distribution of income remains appalling: 77 per cent of the world population earns 15 per cent of its income, and the levels of unemployment remain high, well above those of the postwar period: unemployment has in fact become a chronic and long-term problem. PNUD, Desarrollo Humano: Informe 1991, Bogotá, PNUD, 1991, pp. 66 and 79.

67 R.N. KIWANUKA, "Developing Rights: The UN Declaration on the Right to Development", 35 Netherlands International Law Review (1988) pp. 265-269 and 272; P. MACALISTER-SMITH, "The Notion of Development as a Right: Reflections from an International Perspective", in M.P. SiNGH, Comparative Constitutional Law, Lucknow (India), Eastern Book Co., 1989, pp. 317-319, 323 and 325.

68 IAN Brownlie, The Human Right to Development, London, Commonwealth Secretariat (Occasional Paper Series), 1989, pp. 16-17. 
contributed to draw closer attention to the minimum or basic necessities of life as a basis for entitlements. ${ }^{69}$ Moreover, the formulation of the right to development, by revealing its individual and collective dimensions and being sometimes regarded as a "synthesis" of a great many human rights, contributes to focus on the totality of means required for a comprehensive and integrated implementation of all interrelated human rights standards, with apparently more emphasis on economic, social and cultural rights. ${ }^{70}$ In fact, the right to development has lately had judicial recognition, in the Guinea/Guinea Bissau Maritime Delimitation case, as pertinently recalled by Ian Brownlie-in its award of 18 February 1983, the Court of Arbitration which decided the case referred to "the legitimate claims" of the parties as developing States, and to "the right of the peoples involved to a level of economic and social development which fully preserves their dignity". ${ }^{71}$

The issue of the implementation or vindication of the right to development can be properly considered within the universe of international human rights law. By and large, human rights which have found expression in multiple instruments at global and regional levels also form the object of groups of provisions whose functions may appear different but are in fact complementary, such as: to protect the life and physical integrity of human beings and to secure the exercise of other fundamental rights and freedoms; to prevent and eliminate all forms of discrimination; and to secure minimum conditions of living. ${ }^{72}$

Human rights range substantively from those which impose limits to State intervention (e.g., right to life, right not to be ill-treated, liberty and security of person, freedoms of thought, conscience, religion and opinion, freedom of movement) to those which require State action (e.g., right to work and to an adequate standard of living, including food, housing and clothing; right to health and to social security; right to organize trade unions; right to education). ${ }^{73}$ Human rights range procedurally from those which can be vindicated by the victims themselves (or their representatives) to those which involve a complex web of actors, namely, the victims themselves, interest groups, judges, legislators and the administration. The normative-judicial model, suitable to the implementation of individual rights, appears inadequate to the implementation of, for example, rights pertaining to human collectivities, the protection of which may require the mobilization of public

69 P. MACAlister-Smith, loc. cit. n. 67 at pp. 317 and 325-326; I. BrownLIE, loc. cit. n. 68 at pp. 23-24.

70 I. Brownlie, loc. cit. n. 68 at pp. 12 and 22; P. MACAlisTER-SMITH, loc. cit. n. 67 at p. 317.

71 I. BROWNLIE, loc. cit. n. 68 at pp. 1-2, and cf. p. 13 n. 1.

72 A. KIss, "Définition et nature juridique d'un droit de l'homme à l'environnement", in: Environnement et Droits de l'Homme (ed. P. KROMARECK), Paris, UNESCO, 1987, p. 14.

73 A. EIDE, "Maldevelopment and 'the Right to Development': a Critical Note with a Constructive Intent", Hague Colloquy, loc. cit. n. 46 at p. 400. 
funds and resources. The basic shortcoming of the judicial control model is that it treats all rights in a rather undifferentiated way starting from the assumption that they are all susceptible of being vindicated by the same method. ${ }^{74}$

In practice rights pertaining to human collectivities seem to call for a distinct approach to the means and the institutional arrangements for their implementation or vindication. Violations of those rights may affect so many individuals that individual litigation may prove unsuitable or unjustified, and it may happen that national rules of locus standi end up by denying standing. ${ }^{75}$ It is clear that the "justiciability" of a right cannot be taken as a conditio sine qua non of the latter's existence and recognition: there are rights which today cannot properly be vindicated before a tribunal by their active subjects ("titulaires"). ${ }^{76}$ This point needs further reflection and considerable rethinking of international human rights law.

On the other hand, it can be argued that, having been brought into the realm of international human rights law, the right to development may in concrete cases well rely on the operation of the means of implementation proper to the international protection of human rights (basically, petitioning, reporting and fact-finding). To this effect a range of possible courses of action may be contemplated in the future which might be pursued, first, at the initiative of the human beings concerned, individually and collectively (communities, associations, groups), as the active subjects of the right to development. Secondly, the possibility of initiatives by States acting on behalf of peoples for their protection should not be discarded. Clear indications to this effect can be found in the applications instituting proceedings before the International Court of Justice by New Zealand (against France) in the Nuclear Tests case (1973-1974), and by Nauru (against Australia) in the Phosphate Lands case (1989, since withdrawn).

It seems that it is particularly the methods of human rights protection that the right to development is more likely to rely on for its implementation. The 1986 Declaration in its Preamble in fact refers to the relevant instruments of the United Nations and its special agencies. Finally, the implementation of the right to development as a human right, given the "individual" and "collective" dimensions of the right at issue and its comprehensive nature, may prove to be a complex and multi-faceted one.

74 A. Cassese, A. Clapham and J. Weiler, 1992-What are Our Rights?, Florence, European University Institute, 1989, pp. 25 and 53-54.

75 Ibid, p. 68.

76 A. Kiss, loc. cit. n. 72 at p. 24. 


\section{THE RIGHT TO DEVELOPMENT IN ITS RELATION TO OTHER HUMAN RIGHTS}

We should be guarded against the pitfalls of an inadequate compartmentalization of human rights, first, because it hardly reflects the reality of their implementation and secondly, because it may pave the way to the invocation of undue restrictions to the exercise of certain rights. The proposed classification of individual, social and peoples' rights should be properly approached on the understanding that one category of rights should not prescind from the existence of others. By the same token, the rights of certain categories of protected persons, regarded as belonging to particularly vulnerable groups and standing in need of special protection-such as rights of workers, of women, of the child, of the elderly, of disabled persons-should be approached on the understanding that they are complementary to those enshrined in general human rights treaties. Irrespective of whether the protection of rights vis-à-vis the State (fundamental freedoms) or the guarantee of rights by the State is concerned, the implementation of instruments relating to rights of distinct categories of protected persons, or to a distinct kind of protection sought, is to be taken as complementary to that of general treaties on human rights protection, the two UN Covenants on Human Rights and the three regionalEuropean, American and African-Conventions. ${ }^{77}$

In line with the more lucid thinking in international human rights law, it is a merit of the 1986 UN Declaration on the Right to Development that it provides guidelines for approaching the relation between the right to development and other human rights. In three significant passages (Articles 6(2), 9(1) and Preamble), the declaration stresses that all human rights are indivisible and interdependent and that, in order to promote development, equal and urgent attention should be given to the implementation of civil, political, economic, social and cultural rights, and thus the observance of certain human rights cannot justify the denial of others. Likewise, all aspects of the right to development are indivisible and interdependent and each of them is to be considered in the context of that right as a whole. The Declaration therefore echoes the endorsement, by the celebrated UN General Assembly Resolution $32 / 130$ of 1977 , of the thesis of the indivisibility and interdependence of all human rights advanced by the 1968 Proclamation of Tehran, the

77 A.A. CANÇAdo Trindade, A Questão da Implementacão Internacional dos Direitos Econômicos, Sociais e Culturais: Evolucão e Tendências Atuais, San José/Costa Rica, Instituto Interamericano de Derechos Humanos (VII Curso Interdisciplinario), 1989, pp. 7-8; A.A. CANÇADO TRINDADE, "Coexistence and Co-ordination of Mechanisms of International Protection of Human Rights (At Global and Regional Levels)", 202 Recueil des Cours de L'Académie de Droit International (1987) p. 57. 
roots of which may be traced back to the 1948 Universal Declaration and its preparatory work undertaken by the UN Commission on Human Rights. ${ }^{78}$

The globalist perspective pursued by the United Nations was prompted by the fundamental changes undergone by contemporary international society, inter alia, decolonization, capacity of massive destruction, population growth, environmental conditions, energy consumption. The globalist conception, as externalized by UN GA Resolutions 32/130, 39/145, 43/113, 43/114, 43/125 and by the Declaration on the Right to Development, has contributed to focus on the promotion and protection of the rights pertaining to human collectivities and on the search for solutions of gross and flagrant violations of human rights.

The globalist approach was soon to have repercussions and thus paved the way for distinct solutions at regional level. On the African continent, the draftsmen of the 1981 African Charter on Human and Peoples' Rights opted for the inclusion of a catalogue of civil and political rights (Articles 3-14), economic, social and cultural rights (Articles 15-18), and peoples' rights (Articles 19-24), with a common mechanism of implementation (Articles 46-59 and 62). On the European continent, the Council of Europe adopted the First Protocol to the European Social Charter in 1987, expanding the list of rights protected under the latter. Finally on the American continent, the OAS adopted the Additional Protocol to the American Convention on Human Rights Relating to Economic, Social and Cultural Rights in 1988, incorporating certain economic, social and cultural rights to the Inter-American system of human rights protection. ${ }^{79}$ There could hardly be a pretense of an antagonism of solutions at global (United Nations) and regional levels: the instruments of protection were complementary to each other and had an overriding identity of purpose.

The right to development, as propounded by the 1986 Declaration reinforces existing rights and their interdependence and indivisibility while the globalist approach discloses the complementarity between so-called "individual" and "collective" rights and preserves the indivisibility of rights with predominantly individualist and collectivist orientations or inclinations. ${ }^{80}$ Following this line of thought the requirements of material development cannot be invoked to justify restrictions to the exercise of guaranteed human rights $^{81}$ (cf. UN GA Resolution 37/199).

In view of its comprehensive nature the right to development is commonly said to have an "individual" and a "collective" (social) dimension, but simply distinguishing between individual and collective rights would amount to

78 Ibid, pp. 8 and 59.

79 A.A. CANÇADo Trindade, A Questão da Implementafão ..., op. cit. n. 77 at pp. 9-10, 12 and 29. 80 Ph. Alston, loc. cit. n. 52 at pp. 107-109.

81 A. EIDE, loc. cit. n. 74 at pp. 402 and 410. 
reducing the substratum of these rights to the means of their exercise. ${ }^{82}$ All these rights in a way have a social dimension in that they are related to the community in varying degrees, while solidarity is not the exclusive attribute of any category of rights. ${ }^{83}$ An atomized or fragmented view of human rights can easily be misleading: for example, the assertion that the right to a clean environment brings about limitations of the exercise of some economic and social rights is neglectful of the fact that the right in question essentially purports to expand and reinforce existing rights. ${ }^{84}$ So has the right to development, and this may well bring about adjustments to render new rights effective.

Reversely, a denial of the right to development is bound to entail adverse consequences for the exercise of civil and political as well as economic, social and cultural rights. The recent search for more effective means of implementing economic, social and cultural rights was surely undertaken under the influence of the conception of fundamental unity and indivisibility of human rights. The formulation of the right to development could only have been undertaken in light of that conception and indivisibility. The phenomenon we witness in our days is not that of a succession, but rather one of expansion and strengthening of recognized human rights.

The atomized outlook of human rights with its distortions is in accordance with the theory of "generations" of rights. But human rights, whichever way they are classified, disclose an essentially complementary nature and interact with each other; they do not "replace" each other. Moreover, the analogy of the "generational succession" of rights does not appear historically sound and developments on the matter in municipal and international law do not seem to have taken place pari passu. While in the internal law of many countries the recognition of social rights took place subsequently to that of civil and political rights, this did not occur at the international level, as exemplified by the various international labour conventions, some of them preceding the adoption of conventions devoted to civil and political rights. It is important, even in our days, to reduce or bridge the gap which seems to persist between the constitutionalist and internationalist outlooks on the matter. ${ }^{85}$

Some concluding remarks remain to be made. First, the right to development-like the right to a healthy environment-discloses an inter-

82 J.-B. Marie, "Relations between Peoples' Rights and Human Rights: Semantic and Methodological Distinctions", 7 Human Rights Law Journal (1986) pp. 197-200.

83 Ibid, pp. 199-200.

84 M. Ali Mekouar, "Le droit à l'environnement dans ses rapports avec les autres droits de l'homme", Environnement et Droits ..., op. cit. n. 72, at pp. 91-105.

85 A.A. Cançado Trindade, A Questão da Implementação ..., op. cit. n. 77, pp. 9-10; Ph. Alston, "A Third Generation of Solidarity Rights: Progressive Development or Obfuscation of International Human Rights Law?", 29 Netherlands International Law Review (1982) pp. 316317 , and cf. pp. 307-322. 
temporal dimension ${ }^{86}$ in the international protection of human rights which has not yet been sufficiently explored to date. This dimension encompasses both the "dynamic" interpretation of human rights treaties and instruments and their actual application in the cas d'espèce (e.g., the gradual crystallization of the notion of "potential" victims). ${ }^{87}$ Secondly, the recent progress in the search for a more effective implementation of economic, social, and cultural rights and in the formulation of the right to development bears witness of the considerable advances achieved at the doctrinal level by the conception of the indivisibility of rights. The acknowledgement of these advances, however, cannot make abstraction of the endeavours, at the normative level, towards the identification of a nucleus of non-derogable rights of universal acceptance (e.g., the right of life, the right not to be subjected to torture or slavery, the right not to be condemned by retroactive application of penal provisions).

This reassuring consolidation of a hard core of fundamental non-derogable rights, as a definitive achievement of civilization, has not taken place pari passu to developments at the procedural level, where the absence of a "hierarchy" between the distinct mechanisms of protection seems to continue to prevail. These mechanisms have reinforced each other, being essentially of a complementary nature, as evidenced, for example, by the test of the primacy of the most favourable provision to the alleged victims.

In view of the diversity of the means of protection, there seems to be no logical or juridical bar against advancing, concomitantly, in the search at the substantive level for an expansion of a universal nucleus of non-derogable rights, and, at the procedural level, for an increasingly more effective implementation of social rights. While such expansion of the hard core of fundamental rights cannot be achieved for the time being, the current attitude consists of focusing on devising and improving guarantees with regard to all human rights (both non-derogable and derogable).

The efforts towards a possible expansion of the nucleus of non-derogable rights surely constitute a commendable step for the near future, particularly in view of the distortions and abuses perpetrated during the chronic and pathologically prolonged states of exception and suspensions of rights in the recent history of various countries, with their consequent reiterated, systematic and large-scale violations of human rights. Moreover, taking the proposed categories of rights as an indissoluble whole and considering that the observance of certain social rights and of the right to development has a direct bearing upon the exercise of even certain classical rights of freedom (civil and political), nothing would impede, epistemologically, that in the future

86 For a comprehensive study, from the perspective of international environmental law, cf. E. Brown Weiss, In Fairness to Future Generations: International Law, Common Patrimony, and Intergenerational Equity, Tokyo/Dobbs Ferry, N.Y., U.N.U./Transnational Publs., 1989.

87 A.A. Cançado Trindade, “Co-existence and Coordination ...", loc. cit. n. 77 at pp. 243-299. 
some of the former rights (e.g., right to work, right to education) and the rights to development and to a healthy environment would or could also come to integrate with that "expanded" hard core of non-derogable rights.

The recognition of the right to a healthy environment ${ }^{88}$ enriches and reinforces existing human rights and brings to the fore other rights, e.g., the much-needed right of citizen participation which, in turn, requires the effectiveness of the rights to information and to education (in environmental matters). In the same way, environmental protection can be pursued through the vindication of existing rights. ${ }^{89}$ This bears witness of the indivisibility of human rights.

The same could be said of the recognition of the right to development as a human right. The interrelatedness of, for example, the right to life in its wider sense (encompassing the adequate conditions for a dignified standard of living) and the right to development is self-evident as the latter requires all possible endeavours to be made to overcome the obstacles (of destitution and underdevelopment) preventing the fulfilment of basic human needs. ${ }^{90}$

\section{CONCLUDING REMARKS: THE INSTRUMENTALIZATION OF THE RIGHT TO DEVELOPMENT AS A HUMAN RIGHT (POSSIBLE MECHANISMS)}

It is to be expected that the experience accumulated in the implementation of human rights protection will be of use to the implementation of environmental protection and of the right to development. Some inspiration may be derived from the experience of the methods of reporting ${ }^{91}$ and fact-finding.

Since the 1986 UN Declaration, which brought the right to development into the realm of international human rights law, refers in its Preamble to relevant instruments of the United Nations and its specialized agencies relating to

88 As in the African Charter on Human and Peoples' Rights, Art. 24, and in the Additional Protocol to the American Convention on Human Rights in the Area of Economic, Social and Cultural Rights, Art. 11.

89 The right to privacy, the right to the peaceful enjoyment of one's possessions-as recent case law indicates, particularly under the European Convention on Human Rights.

90 Not surprisingly, the UN Working Group of Government Experts on the Right to Development recommended in 1984, inter alia, that particular attention should be paid to the basic needs and aspirations of vulnerable or disadvantaged and discriminated groups. Cf. P.J.I.M. De WAART, "The Inter-Relationship between the Right to Life and the Right to Development", in The Right to Life in International Law (ed. B.G. RAMCHARAN, Dordrecht, Nijhoff/Kluwer, 1985, pp. 89 and 9192; and cf. A.A. CanÇAdo Trindade, "Legal Dimensions of the Right to Development as a Human Right: Some Conceptual Aspects", 12 Revista del Instituto Interamericano de Derechos Humanos (1990) pp. 81-95.

91 Cf. United Nations, Manual on Human Rights Reporting, New York, UN Centre for Human Rights/UNITAR, 1991, pp. 3-201. 
human rights, it is proper to consider the suitability of existing mechanisms of human rights protection for the instrumentalization of the right to development. Accordingly, in the debates of the 1990 UN Global Consultation on the Right to Development as a Human Right, we raised four possibilities for consideration in this connection. First, a communications system along the lines of the procedure provided in ECOSOC Resolution 1503 in case of an alleged denial or violation of the right to development (e.g., growth of unemployment, refusal of access to education, housing and health services, etc.) amounting to gross or massive and flagrant violation of human and peoples' rights; secondly, the adoption of a system of periodic State reports to be forwarded to an organ like the UN Commission on Human Rights on the basis of experience accumulated in this area (e.g., under the ILO and the UN); thirdly, the establishment of a monitoring system by a group of experts or a special rapporteur in situations manifestly resulting from a condition of underdevelopment or with a direct bearing on the realization of the right to development as a human right, in coordination with other supervisory organs (particularly those with a concrete mandate under general treaties of human rights protection); fourthly, the undertaking of in depth studies by an organ such as the UN Sub-Commission on Prevention of Discrimination and Protection of Minorities aiming at, for example, identifying specific key issues pertaining to the right to development as a human right (e.g., health, housing, access to education and information, etc.). ${ }^{92}$ During the debates of the UN Global Consultation we further pondered about a combination of two or more of the above-suggested methods, which might prove suitable given the comprehensive nature of the right to development as a human right, encompassing the protection of the human person and of peoples in the civil, political, economic, social and cultural domains; besides the abovesuggested were not exclusive of other and possibly new methods of implementation that could be devised. ${ }^{93}$

The recognition and formulation of the right to development as a human right has introduced ethical considerations in the conduct and assessment of contemporary international relations. In humanizing the process of development, it is now high time to turn our attention to devising some form of institutionalized implementation of the right to development as a human right in the years to come.

92 A.A. CANÇAdo Trindade, Direito das Organizaçooes In irnacionais, Brasilia, Escopo Ed., 1990, pp. 327-328 and 343-345; A.A. CANÇADo TRINDADE, "As Consultas Mundiais das Nações Unidas sobre a Realização do Direito ao Desenvolvimento como um Direito Humano", 72/74 Boletim da Sociedade Brasileira de Direito Internacional (1990-1991) pp. 91-100.

93 A.A. CançAdo Trindade, Direito das Organizaçóes ..., op. cit. supra n. 92, p. 345. 


\section{ANNEX \\ DECLARATION ON THE RIGHT TO DEVELOPMENT \\ (ADOPTED BY THE UN GENERAL ASSEMBLY RESOLUTION 41/128 OF 4 \\ DECEMBER 1986)}

The General Assembly,

Bearing in mind the purposes and principles of the Charter of the United Nations relating to the achievement of international cooperation in solving international problems of an economic, social, cultural and humanitarian nature, and in promoting and encouraging respect for human rights and fundamental freedoms for all without distinction as to race, sex, language or religion,

Recognizing that development is a comprehensive economic, social, cultural and political process, which aims at the constant improvement of the well-being of the entire population and of all individuals on the basis of their active, free and meaningful participation in development and in the fair distribution of benefits resulting therefrom,

Considering that under the provisions of the Universal Declaration of Human Rights everyone is entitled to a social and international order in which the rights and freedoms set forth in that Declaration can be fully realized,

Recalling the provisions of the International Covenant on Economic, Social and Cultural Rights and of the International Covenant on Civil and Political Rights,

Recalling further the relevant agreements, conventions, resolutions, recommendations and other instruments of the United Nations and its specialized agencies concerning the integral development of the human being, economic and social progress and development of all peoples, including those instruments concerning decolonization, the prevention of discrimination, respect for and observance of, human rights and fundamental freedoms, the maintenance of international peace and security and the further promotion of friendly relations and cooperation among States in accordance with the Charter,

Recalling the right of peoples to self-determination, by virtue of which they have the right freely to determine their political status and to pursue their economic, social and cultural development,

Recalling also the right of peoples to exercise, subject to the relevant provisions of both International Covenants on Human Rights, full and complete sovereignty over all their natural wealth and resources,

Mindful of the obligation of States under the Charter to promote universal respect for and observance of human rights and fundamental freedoms for all without distinction of any kind such as race, colour, sex, language, religion, political or other opinion, national or social origin, property, birth or other status,

Considering that the elimination of the massive and flagrant violations of the human rights of the peoples and individuals affected by situations such as those resulting from colonialism, neo-colonialism, apartheid, all forms of racism and racial discrimination, foreign domination and occupation, aggression and threats against national sovereignty, national unity and territorial integrity and threats of war would contribute to the establishment of circumstances propitious to the development of a great part of mankind,

Concerned at the existence of serious obstacles to development, as well as to the complete fulfilment of human beings and of peoples, constituted, inter alia, by the denial 
of civil, political, economic, social and cultural rights, and considering that all human rights and fundamental freedoms are indivisible and interdependent and that, in order to promote development, equal attention and urgent consideration should be given to the implementation, promotion and protection of civil, political, economic, social and cultural rights and that, accordingly, the promotion of, respect for and enjoyment of certain human rights and fundamental freedoms cannot justify the denial of other human rights and fundamental freedoms,

Considering that international peace and security are essential elements for the realization of the right to development,

Reaffirming that there is a close relationship between disarmament and development and that progress in the field of disarmament would considerably promote progress in the field of development and that resources released through disarmament measures should be devoted to the economic and social development and well-being of all peoples and, in particular, those of the developing countries,

Recognizing that the human person is the central subject of the development process and that development policy should therefore make the human being the main participant and beneficiary of development,

Recognizing that the creation of conditions favourable to the development of peoples and individuals is the primary responsibility of their States,

Aware that efforts at the international level to promote and protect human rights should be accompanied by efforts to establish a new international economic order,

Confirming that the right to development is an inalienable human right and that equality of opportunity for development is a prerogative both of nations and of individuals who make up nations,

Proclaims the following Declaration on the Right to Development:

\section{Article 1}

1. The right to development is an inalienable human right by virtue of which every human person and all peoples are entitled to participate in, contribute to, and enjoy economic, social, cultural and political development, in which all human rights and fundamental freedoms can be fully realized.

2. The human right to development also implies the full realization of the right of peoples to self-determination, which includes, subject to the relevant provisions of both International Covenants on Human Rights, the exercise of their inalienable right to full sovereignty over all their natural wealth and resources.

\section{Article 2}

1. The human person is the central subject of development and should be the active participant and beneficiary of the right to development.

2. All human beings have a responsibility for development, individually and collectively, taking into account the need for full respect for their human rights and fundamental freedoms as well as their duties to the community, which alone can ensure the free and complete fulfilment of the human being, and they should 
therefore promote and protect an appropriate political, social and economic order for development.

3. States have the right and the duty to formulate appropriate national development policies that aim at the constant improvement of the well-being of the entire population and of all individuals, on the basis of their active, free and meaningful participation in development and in the fair distribution of the benefits resulting therefrom.

\section{Article 3}

1. States have the primary responsibility for the creation of national and international conditions favourable to the realization of the right to development.

2. The realization of the right to development requires full respect for the principles of international law concerning friendly relations and cooperation among States in accordance with the Charter of the United Nations.

3. States have the duty to cooperate with each other in ensuring development and eliminating obstacles to development. States should realize their rights and fulfil their duties in such a manner as to promote a new international economic order based on sovereign equality, interdependence, mutual interest and cooperation among all States, as well as to encourage the observance and realization of human rights.

\section{Article 4}

1. States have the duty to take steps, individually and collectively, to formulate international development policies with a view to facilitating the full realization of the right to development.

2. Sustained action is required to promote more rapid development of developing countries. As a complement to the efforts of developing countries, effective international cooperation is essential in providing these countries with appropriate means and facilities to foster their comprehensive development.

\section{Article 5}

States shall take resolute steps to eliminate the massive and flagrant violations of the human rights of peoples and human beings affected by situations such as those resulting from apartheid, all forms of racism and racial discrimination, colonialism, foreign domination and occupation, aggression, foreign interference and threats against national sovereignty, national unity and territorial integrity, threats of war and refusal to recognize the fundamental right of peoples to self-determination. 


\section{Article 6}

1. All States should cooperate with a view to promoting, encouraging and strengthening universal respect for and observance of all human rights and fundamental freedoms for all without any distinction as to race, sex, language or religion.

2. All human rights and fundamental freedoms are indivisible and interdependent; equal attention and urgent consideration should be given to the implementation, promotion and protection of civil, political, economic, social and cultural rights.

3. States should take steps to eliminate obstacles to development resulting from failure to observe civil and political rights, as well as economic, social and cultural rights.

\section{Article 7}

All States should promote the establishment, maintenance and strengthening of international peace and security and, to that end, should do their utmost to achieve general and complete disarmament under effective international control, as well as to ensure that the resources released by effective disarmament measures are used for comprehensive development, in particular that of the developing countries.

\section{Article 8}

1. States should undertake, at the national level, all necessary measures for the realization of the right to development and shall ensure, inter alia, equality of opportunity for all in their access to basic resources, education, health services, food, housing, employment and the fair distribution of income. Effective measures should be undertaken to ensure that women have an active role in the development process. Appropriate economic and social reforms should be carried out with a view to eradicating all social injustices.

2. States should encourage popular participation in all spheres as an important factor in development and in the full realization of all human rights.

\section{Article 9}

1. All the aspects to the right to development set forth in the present Declaration are indivisible and interdependent and each of them should be considered in the context of the whole.

2. Nothing in the present Declaration shall be construed as being contrary to the purposes and principles of the United Nations, or as implying that any State, group or person has a right to engage in any activity or to perform any act aimed at the violation of the rights set forth in the Universal Declaration of Human Rights and in the International Covenants on Human Rights. 


\section{Article 10}

Steps should be taken to ensure the full exercise and progressive enhancement of the right to development, including the formulation, adoption and implementation of policy, legislative and other measures at the national and international levels. 